\title{
Eduard Suess: the first honorary president of the Geologische Vereinigung, is 190 years old
}

\author{
A. M. Celal Sengör ${ }^{1} \cdot$ Wolf-Christian Dullo ${ }^{2}$
}

Published online: 27 September 2021

(c) The Author(s) 2021

When in 1910 some of the foremost German geologists assembled in Frankfurt-am-Main in Germany with a view to founding the Geologische Vereinigung as an international learned society, they asked the man, at the time considered to be the dean of geologists in the whole world, to accept the honorary presidency of their new organisation. He graciously accepted. After more than a century, we today hail that man as possibly the greatest geologist who ever lived and without doubt the founder of modern global geology. In the first meeting of the new society, three distinguished members, Gustav Steinmann, Wilhelm Salomon and Otto Wilckens read papers on three different chapters of the last volume of his magnum opus, Das Antlitz der Erde (The Face of the Earth), published the previous year and those papers were published in the Geologischpe Rundschau, the organ of the Geologische Vereinigung, which we are proud to be able

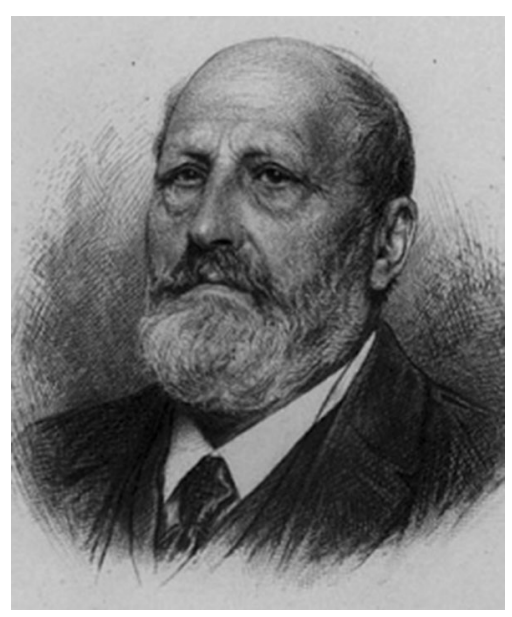

Eduard Suess

Wolf-Christian Dullo

cdullo@geomar.de

Istanbul, Turkey

2 Kiel, Germany to continue publishing with an ever-increasing international audience with a sense of service to our science.

Our first honorary president, Eduard Suess, was born on 20th August 1831 in London to Austrian parents who happened to be there temporarily for business reasons. The family returned to Prag, where Suess grew up as a quadrilingual child. In the last year of his high-school education the family moved to Vienna, where Suess enrolled in the Technical University upon his family's wish. However, the 1848 events interfered and Suess left the Technical University and became a volunteer in the Hofmineralienkabinett, the ancestor of the great Museum of Natural History in Vienna. In 1857 he was appointed professor in the University of Vienna and till his retirement in 1901 created one of the grandest geological schools in the history of our science.

Suess regarded geology as a global science right from the beginning: the local stratigraphy of the Vienna Basin, where he took his students for excursions, became the basis of the idea of eustatic movements; a water catastrophe in the world-famous Wieliczka salt mines, provided the excuse to develop the idea that mountain belts form not by magmadriven vertical uplift, but by lateral shortening; student excursions to southern Italy, together with colleagues from Germany, led to the recognition of simultaneous shortening in the external parts of orogens with stretching and subsidence in the internal parts. Unlike all his predecessors Suess did not rush to print with these revolutionary ideas: in 1875 his little book, Die Entsehung der Alpen (The Origin of the Alps) announced the birth of a new era in geology, not only because of the novel ideas it contained, but also because it presented a truly global review of the then best-known mountain belts the world over plus a masterful analysis of the Cenomanian transgression.

In 1883 Suess began publishing his global tectonics masterpiece, Das Antlitz der Erde. It took him 26 years to complete the four ponderous volumes and as soon as it was completed, it was translated into English, French and Spanish, partly Italian, and one chapter of it to Esperanto! The 
French translation began before Suess finished writing the entire book.

That book is so fundamental, so many of our current concepts go back to it, that it is no longer referenced, much like Newton's Principia or Darwin's Origin. This led, however, to an unfortunate fading of Suess' memory from the collective consciousness of geologists, despite the fact we use his concepts every day. This is unfortunate, not only because it seems ungrateful, but more importantly, because geologists the world over still have so much to learn from him, and so much to remember so as not to use certain concepts incorrectly or not to have to reinvent the wheel.

Some might think that after plate tectonics we no longer need to read Suess. This is a grave misconception. So much of our plate tectonic terminology go back to him that one is surprised at his incredible comprehension of geology: Atlantic and Pacific-type continental margins were his concepts; foredeeps, including deep-sea trenches resulting from massive underthrusting also creating the arc magmatism was his recognition; he first noticed the presence and unity of Gondwana-Land until the Mesozoic; Tethys was his brainchild; recognition of the importance of strike-slip faults, existence of listric faulting, presence of large batholiths (which he named) belong to him. It is impossible to squeeze into this short eulogy all his numerous creations that are still with us.

This incredible man was also busy in public life. His 1862 book on the geology of Vienna is not only the herald of urban geology, but also the reason he was invited to be active in politics. For 30 years he was a member of the Austrian Imperial Parliament. He was instrumental in bringing healthy drinking water to Vienna from the Alps and for regulating the Danube to stop its disastrous floods in the city. These huge engineering projects reduced the death toll from such diseases as typhoid fever and cholera in the imperial capital to a fraction of its previous frightening value. Suess always said that he considered this his greatest achievement. In the parliament he fought to remove the influence of the church on schools. Throughout his professional life he was active in the affairs of the Imperial Academy of Sciences in Vienna, finally serving for 11 years as one of its greatest presidents. As such, he was instrumental in organising scientific expeditions to various parts of the world (the results of one of them led to his discovery of the East African Rift valleys). He created the first cartel of scientific academies in Europe and became its first president.

And this very busy man was an exemplary father to his six children and a loving husband who used to refer to his wife as the 'light of my existence.'

We take pride in remembering our first honorary president on his 190th Anniversary. He still illuminates our path in our endeavours to understand not only our planet, but also others in our Solar System. May his spirit continue to live among us.

\section{A. M. Celal Sengör and Wolf-Christian Dullo.}

Funding Open Access funding enabled and organized by Projekt DEAL.

Open Access This article is licensed under a Creative Commons Attribution 4.0 International License, which permits use, sharing, adaptation, distribution and reproduction in any medium or format, as long as you give appropriate credit to the original author(s) and the source, provide a link to the Creative Commons licence, and indicate if changes were made. The images or other third party material in this article are included in the article's Creative Commons licence, unless indicated otherwise in a credit line to the material. If material is not included in the article's Creative Commons licence and your intended use is not permitted by statutory regulation or exceeds the permitted use, you will need to obtain permission directly from the copyright holder. To view a copy of this licence, visit http://creativecommons.org/licenses/by/4.0/. 